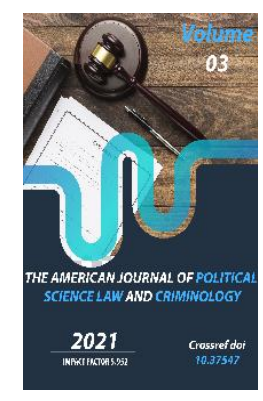

\title{
Problems Of Compensation For Moral Damage Caused To The Consumer
}

Babayev Djahongir Ismailbekovich

Professor, Candidate Of Judicial Science, Department Of Civil Law, Tashkent State University of Law, Uzbekistan

Journal Website:

http://theamericanjour

nals.com/index.php/taj

psic

Copyright: Original

content from this work

may be used under the

terms of the creative

commons attributes

4.0 licence.

\section{ABSTRACT}

The article examines the problems of compensation for moral damage caused to the consumer by defects in goods, work performed or services rendered. The article analyzes domestic and foreign law enforcement practice on the issues of compensation for moral damage to consumers and points to the absence of clear criteria for determining the amount of moral damage both in the Republic of Uzbekistan and in foreign countries. The article points to the existing disagreements between the plaintiffs and the judges in determining the amount of compensation for non-pecuniary damage. The rights of individuals and legal entities to claim compensation for moral damage are distinguished.

\section{KEYWORDS}

Consumer, moral damage, moral suffering, product shortcomings, honor, dignity, compensation, rationality, justice.

\section{INTRODUCTION}

Consumption and fair trade are among the fundamental principles of any democratic society, and the protection of human rights as a consumer is an objective, inevitable rule of law and one of the most important characteristics of such a society. Consumer protection is an integral part of the consumer protection system enshrined in Article 53 of the Constitution of Uzbekistan, since it is the state that guarantees consumer protection. It should be noted that the history of the development of consumer protection dates back to the middle ages. It was then that a law was passed in Austria on the addition of starch to margarine. It was because the market inspector had to be able to determine the 
status of the sale of margarine as butter based on taste. At that time, there were also laws in force establishing liability for the sale of substandard goods. 15th century in Austria, for the sale of milk with the addition of water or sour milk, a measure was used as a punishment according to which the seller had to drink all this milk himself. On the other hand, in France, 16th century, buyers had the right to throw rotten eggs at sellers. In many countries, there is a special position of market inspector, whose duties include overseeing compliance with the rules of the public market, punishing violators and encouraging honest traders.

Violation of consumer rights in the sale of goods, performance of work, and provision of services can cause not only material, but also moral harm. In this case, the person whose rights have been violated may demand from the manufacturer, seller, and contractor, performer adequate compensation for the moral suffering caused to him. The consumer's right to demand compensation for moral damage in case of violation of his rights is understood from the general rules of the institution for the protection of civil rights and special legislation on the protection of consumer rights. In particular, Article 11 of the Civil Code of the Republic of Uzbekistan provides for compensation for non-pecuniary damage as one of the ways to protect civil rights, and Article 22 of the Law "On Protection of Consumer Rights" deals with compensation for moral damage.

Currently, at the level of development of civilized thinking, there is a rule according to which moral damage manifests itself in the form of moral and physical suffering, for which an individual who has experienced such suffering has the right to demand some compensation. In particular, the Decree of the President of the Republic of Uzbekistan No.UP-5464 dated April 5, 2019 «The concept of improving the civil legislation of the Republic of Uzbekistan» sets the task of strengthening the compensatory function of civil legislation by introducing the procedure for calculating moral and material damage [1]. On the basis of the above, non-pecuniary damage is compensated by obtaining compensation for moral suffering and physical pain.

Moral damage to the consumer can be inflicted in any legal relationship in which he is involved. Although non-pecuniary damage is generally considered tort, it can also arise from non-performance of contractual obligations or non-performance of contractual requirements. This situation is also observed in judicial practice. For example, on February 25, 2020, the Karmana inter district Civil Court considered a claim for compensation for material and moral damage caused by violation of consumer rights by the seller's refusal to eliminate defects in the goods, the warranty period of which had not expired. In this case, the court recognized the consumer's demand as justified and ruled to replace the product with a new one and recover 300,000 Uzbek soums in the form of compensation for moral damage [2].

Moral damage caused by the failure to provide the consumer with the necessary information, the inadequacy of the quality of service to the established requirements, the provision of incorrect information, is satisfied at the request of the consumer. In this case, the consumer can provide relevant information about his mental and physical suffering or 
provide documents about the negative impact on his moral state. The specified condition must be accompanied by a medical certificate of adverse health changes or some confirmed evidence of moral suffering. For example, moral suffering can be expressed in the appeal of the buyer to the seller with a demand to replace a defective product, receiving a refusal from the seller, the inability to find the seller within a certain period of time, or the seller's address is incorrectly specified. The same situation is observed when performing work and providing services. For example, a TV set was repaired by a domestic service company and a warranty period was set for it. However, if the TV breaks down during this warranty period, the customer-consumer will be denied or abused, a repair fee will be charged, or the corresponding spare parts will be available later, which causes moral damage. In this case, the consumer has the right to demand compensation from the consumer services enterprise for both moral damage and material damage.

The category of moral damage is a subinstitutional of civil law, which is always somewhat contradictory and cannot be measured by strict criteria. In judicial practice, the plaintiff can also claim the amount that he wishes and considers necessary, without providing any documents or relevant evidence to confirm and accurately measure the amount of non-pecuniary damage, and the court can award compensation for nonpecuniary damage in a significantly reduced amount. In this situation, the court cannot substantiate the reason for the decrease in the amount of non-pecuniary damage, because non-pecuniary damage cannot be assessed on the basis of «physical appearance», which is a key element of measurement in civil law. Thus, when determining the amount of non-pecuniary damage, the court, as a rule, limits itself to citing the general criteria set out in Articles 1021-1022 of the Civil Code. In most cases, these cases are based on the circumstances of the case, the degree of fault of the inflictor of harm and the requirements of reasonableness and fairness. However, there is no clear measure on these criteria. However, these criteria are spiritual and personal. In this sense, the plaintiffs can demand trillions, billions and hundreds of millions of compensation for non-pecuniary damage, as a result of which the court will award compensation in the amount of several hundred thousand soums. This provision is found all over the world. In the United States, for example, there are many illogical claims for compensation for moral and material harm, which lawyers often call a special term frivolous lawsuit. In most cases, this is due to the boundlessness of human imagination, expressed in claims of up to a trillion dollars, and in almost all cases these claims are not even accepted for consideration by the courts [3].

The moral damage caused to the consumer is, first of all, the moral, spiritual and physical suffering experienced as a result of the violation of his rights as a person, as well as the moral pain caused by information defaming honor and dignity specified in Article 100 of the Civil Code. In this regard, an obvious problem arises that the provisions of Article 100 of the Civil Code can be applied in case of violation of consumer rights, the connection of the provisions of this article with moral damage caused to the consumer as a whole. In our opinion, Article 100 of the Civil Code 
states that any person must be compensated for moral damage caused by an encroachment on his honor and dignity. In this case, the consumer, like any other consumer, has the right to demand compensation for moral damage caused to him in accordance with this article. Thus, the consumer has the right to demand compensation for moral damage caused by the violation of his rights, regardless of whether the entrepreneur entered into a contractual relationship with the consumer on the basis of his status.

In law enforcement practice, there is a different approach to compensation for moral damage. In particular, according to the judge of the Supreme Court of the Republic of Uzbekistan J. Tirkashev, moral damage is inflicted on citizens and organizations by defaming their honor and dignity, by disseminating inaccurate information, harming the life and health of citizens, as well as other rights of citizens and legal entities guaranteed by the Constitution of Uzbekistan [4].

In this case, it is arguable that organizations also have «honor and dignity». Nevertheless, the categories of honor and dignity belong only to the individual. On the contrary, organizations can only have a business reputation. Consequently, it is appropriate to compensate for moral damage to a citizen, and not to organizations, although there is a reference to the fact that a legal entity may also have the right to demand compensation for moral damage in accordance with part nine of Article 100 of the Civil Code.

The first paragraph of clause 2 of the Resolution of the Plenum of the Supreme Court of the Republic of Uzbekistan «On some issues of the application of legislation on compensation for moral harm» [5] defines the concept of moral damage and states that moral and physical suffering is moral harm. Consequently, the courts must be guided by statutory criteria when determining the amount of non-pecuniary damage. O. Okyulov, in his interpretation of the concept of moral harm, defines the terms "physical pain» and «moral suffering», and also indicates that the presence of one of these two components is sufficient to cause moral harm, and if both of these components are manifested simultaneously, the degree of moral damage and liability should be higher [6]. In our opinion, the physical pain experienced by the consumer in connection with harm to health as a result of violation of his rights is assessed as moral damage and he should be paid some compensation. An example of the simultaneous expression of physical pain and mental suffering is damage to health by a product that has defects and rejections of claims for compensation, as well as accusations of fraud and deceit on the consumer. In the case of a combination of these cases, the amount of compensation for non-pecuniary damage should be higher.

In the legal literature, there are many opinions about the legal nature of compensation for moral damage. According to I.I. Nasriev, compensation will at least mitigate the suffering caused. As a result, there is no way to recover moral damage, and it is impossible to eliminate it by payment. It can only be compensated for in a certain value [7]. B.M. Khamrokulov, on the contrary, argues that the term "compensation» in relation to moral damage cannot be used, since it is impossible to realistically assess the amount of moral damage, therefore it is necessary to 
compensate for moral damage, which serves only as consolation for the victim, and also emphasizes that compensation is not the restoration of the violated right.[8]

In addition, it should be noted that the legal determination of the amount claimed by the victim in the event of non-pecuniary damage depends primarily on the determination of the amount to be recovered and the proper application of the rules of proportionality, fairness and fairness. This is especially important when protecting consumer rights. After all, when a consumer, unlike other subjects, as the weak side of legal relations, requires compensation for moral damage, it is necessary to establish a higher amount of compensation in relation to him. Thus, violation of consumer rights by a professional counterparty with higher legal, professional knowledge and skills than a consumer is different from causing moral damage between equal participants in another type of legal relationship. In this regard, when dealing with moral harm, given that the consumer is a weak side, and the other party knows about this, first of all, it is necessary to pay attention to the proportionality of the illegal act committed by the counterparty and the amount of compensation.

Article 22 of the Law "On Protection of Consumer Rights" states that the tort feasor must pay compensation if he is at fault. This provision on the payment of compensation for non-pecuniary damage to the consumer is also provided for in article 1021 of the Civil Code. Since in the event of harm to the life and health of the consumer as a result of defects in the goods (work, service), the question of innocent liability in the legislation remains open. Article 1020 of the Civil Code provides for exemption from liability for damage caused by defects in goods (works, services) in the following two cases: a) the damage was caused by force majeure; b) violation by the consumer of the established rules for storing or using goods (results of work, services). The above article does not define the absence of fault as a basis for exoneration from liability. It turns out that the shortcomings of the goods are also the fault of the manufacturer, seller, contractor and executor. However, it is important to determine that compensation for harm, including moral damage, caused by defects caused by natural wear and tear of the goods, the expiration of the service life of its parts, without direct human influence, should be regarded as innocent responsibility. In this regard, it is appropriate to draw attention to the rule of absence of guilt as a basis for exemption from liability for failure to fulfill the obligations provided for in part three of Article 333 of the Civil Code. That is, if the basis for exemption from liability under contractual obligations is the absence of guilt, then the basis for exemption from liability for harm caused by the lack of goods (work, services) are force majeure circumstances and the actions of the victim. Consequently, the counterparty must prove his innocence in the relationship of the obligation in order to be exempted from liability for moral damage caused to the consumer, and in relation to the tort, the counterparty must prove force majeure circumstances and the guilt of the victim.

In civil law, the issue of determining the amount of compensation for moral damage is the most relevant and intractable, and therefore is a measure of responsibility that requires different interpretations and 
approaches. According to M.M. Mamasiddikov in judicial practice, there are a number of problems with determining the amount of the penalty when considering and resolving cases of compensation for moral damage. The fact that at present there is no clear legal concept on this issue, and even the Resolution of the Plenum of the Supreme Court does not provide an appropriate explanation, indicates the relevance of this issue [9]. According to $\mathrm{N}$. Egamberdiyeva, when determining the amount of moral damage, one should proceed from the degree of guilt of the offender. After determining the degree of guilt, it is also necessary to determine its amount. The size issue is also not clearly regulated in the legislation. The decision on the amount of damage is left to the discretion of the courts themselves [10].

In our opinion, in addition to the above criteria (the nature of guilt and suffering), rationality and justice are also decisive factors in determining the amount of compensation for moral damage. The current legislation does not define the criteria of fairness and reasonableness. However, these concepts are understood and interpreted by everyone in a different way, based on their own perception of the world and society. Consequently, these concepts have no clear boundaries, volume or dimension. However, when determining the amount of compensation for moral damage, it is necessary to develop a specific approach to the interpretation and application of these concepts. Indeed, the court determines the amount of compensation for non-pecuniary damage by assessing these categories in the course of the proceedings. Thus, the availability of appropriate guidance on how to interpret the concepts of fairness and reasonableness serves to ensure that the courts' approach in this regard is the same. $\mathrm{O}$. Okyulov connects the criterion of justice with the ratio of harm and the compensation established for it, rationality is associated with taking into account the property status of the parties to the legal relationship. In our opinion, the criterion of reasonableness in determining the amount of compensation for moral damage is expressed primarily in a decision that corresponds to reason as an inner feeling. A conclusion that is appropriate for the situation and which many consider reasonable is a reasonable decision. The nature of reasonableness in determining the amount of compensation for moral damage to the consumer is established based on the characteristics of the harm, contradictory actions between the victim and the tortfeasor.

Based on the above analysis, it should be noted that in order to increase the level of consumer protection in Uzbekistan, the priorities of state policy in this area may be the following:

- The need to further harmonize the legal framework of Uzbekistan in the field of consumer protection with European norms and rules, as well as improve national consumer legislation (detailed description of the law on the conditions for the return and exchange of goods; rules for the return of goods, warranty service, etc.);

- Ensuring interaction, functioning and coordination of actions of executive authorities with local governments and public associations of consumers;

- Creation of specialized organizations for independent testing, examination of the quality and safety of goods and services sold on the market; 
- Providing and supporting research in the field of consumer protection;

- Increasing the role of the media in informing consumers about the results of comparative testing of goods and services;

- Ensuring the necessary objectivity and reliability of information about the relevant goods and services, so that consumers can make an informed choice between different offers on the market;

- Creation of an «anti-rating» of enterprises that constantly violate consumer rights;

- Increasing the level of knowledge of consumers through the mandatory introduction of appropriate training courses in secondary and higher educational institutions;

- Introduction of the concept of «absolute responsibility of producers» for all goods and services supplied to the market, creation of a system of incentives for manufacturers and sellers of high-quality and safe products;

- Implementation of measures at the state level to protect consumers from genetically modified organisms, potential risks associated with the use of food additives (for example, strengthening the conditions for their registration, reducing the validity of certificates and quality certificates).

\section{REFERENCES}

1. National Database of Legislation, 06.04.2019, No. 08/19/5464/2891.

2. $10,000,000$ and 300,000 soums of moral damage were recovered in favor of the consumer // https://istemol.uz/ru/archives/4517.
3. Billions, trillions, undecillions. Record claims and payments / http://rapsinews.ru/judicial_analyst/201 40522/271383358.html

4. Tirkashev J. In what order the moral damage is recovered // http://sud.uz/manual-harm-what-it- isrecovered/.

5. https://www.lex.uz/docs/1449509.

6. Commentary to the Civil Code of the Republic of Uzbekistan: Scientific Comments. T. 3. / Ministry of Justice of the Republic of Uzbekistan. Tashkent: Baktria press, - 346 p.

7. Nasriev I.I. Moral damage, some problems of its compensation // Journal of Legal Research. Journal Legal Research. Journal of Law Research. 2017. - №3. - S. 68. // www.tadqiqot.uz

8. Hamroqulov B.M. Improving the basis for compensation for non-pecuniary damage: PhD dissertation. abstract. 24 b.

9. Mamasiddiqov M.M. Procedural features of litigation of disputes arising from labor relations. Tashkent: TSU, 2005. - 102 p.

10. Egamberdieva N.H. Fundamentals and forms of civil liability: PhD dissertation.

- Tashkent: 2006. - 84 p. 